\title{
A Lipopolysaccharide-Induced DNA-Binding Protein for a Class II Gene in B Cells Is Distinct from NF-kB
}

\author{
ELLEN M. GRAVALLESE, ${ }^{1.2 *}$ MARK R. BOOTHBY, ${ }^{1.2}$ CYNTHIA M. SMAS, ${ }^{1}$ AND LAURIE H. GLIMCHER ${ }^{1.2}$ \\ The Department of Cancer Biology, Harvard School of Public Health, ${ }^{1}$ and The Department of Medicine, Harvard
} Medical School, ${ }^{2}$ Boston, Massachusetts 02115

Received 7 March 1989/Accepted 29 April 1989

\begin{abstract}
Class II (Ia) major histocompatibility complex molecules are cell surface proteins normally expressed by a limited subset of cells of the immune system. These molecules regulate the activation of $T$ cells and are required for the presentation of antigens and the initiation of immune responses. The expression of Ia in $B$ cells is determined by both the developmental stage of the $B$ cell and by certain external stimuli. It has been demonstrated previously that treatment of B cells with lipopolysaccharide (LPS) results in increased surface expression of Ia protein. However, we have confirmed that LPS treatment results in a significant decrease in mRNA encoding the Ia proteins which persists for at least $18 \mathrm{~h}$. Within the upstream regulatory region of $A_{\alpha}{ }^{k}$, an NF-kB-like binding site is present. We have identified an LPS-induced DNA-binding protein in extracts from athymic mice whose spleens consist predominantly of $\mathbf{B}$ cells. Binding activity is present in low levels in unstimulated spleen cells and is increased by LPS treatment. This protein binds to two sites in a regulatory region of the Ia $\mathrm{A}_{\alpha}{ }^{k}$ gene, one of which contains the NF-kB-like binding site. DNA fragments containing these sites cross-compete for protein binding. Analysis by DNase I footprinting identified a target binding sequence, named the LPS-responsive element. Although this target sequence contains an NF-KB-like binding site, competition with a mutant oligonucleotide demonstrated that bases critical for $\mathrm{NF}-\kappa \mathrm{B}$ binding are not required for binding of the LPS-inducible protein. Therefore, we hypothesize that this inducible protein represents a new mediator of LPS action, distinct from NF-אB, and may be one mechanism to account for the decrease in mRNA encoding the Ia proteins.
\end{abstract}

The class II (Ia) molecules are a family of cell surface glycoproteins encoded in the I subregion of the major histocompatibility complex (15) on murine chromosome 17. This subregion encodes four class II genes, $A \alpha, A \beta, E \alpha$, and $\mathrm{E} \beta$, which are coexpressed. The cell surface proteins, I-A and I-E, are the products of noncovalent pairing of the $\alpha$ and $\beta$ subunits. These proteins play a critical role in antigen presentation and immune-cell interactions (36). Increased levels of cell surface Ia on B cells increase the ability of these cells to present antigens to T lymphocytes (20). Expression of I-subregion proteins (Ia) and immunoglobulins in B cells is developmentally regulated. As B cells mature from pre-B to mature B cells, immunoglobulin synthesis is initiated and cells express specific immunoglobulin. These cells may differentiate further into antibody-producing plasma cells. Ia antigen is expressed as pre-B cells differentiate, persists in mature B cells, and is lost upon terminal differentiation to antibody-secreting plasma cells $(18,31)$. In addition, external stimuli, such as interleukin-4 (IL-4) (26) and antibodies to B-cell-differentiation antigens including surface immunoglobulin $M$ (22) and immunoglobulin D (17), increase the level of expression of class II antigens on B cells. Although a number of stimuli have been shown to increase the expression of B-cell surface Ia, few signals have been shown to decrease its expression. Recently, however, corticosteroids were shown to reduce the expression of surface Ia on resting and activated murine $B$ cells (21).

Lipopolysaccharide (LPS) is an integral component of the outer membrane of gram-negative bacteria and is a powerful B-cell mitogen. Approximately $30 \%$ of murine B cells respond to LPS by becoming blasts and secreting immunoglobulin (24). This program of immunoglobulin gene activation

\footnotetext{
* Corresponding author.
}

may be mediated in part by the protein NF-kB, which is involved in transcription of the $k$-chain gene. The nuclear localization and binding of NF- $\mathrm{KB}$ to a transcriptional motif within the $\kappa$ light chain enhancer are induced by LPS in pre-B cells $(4,37,38)$. Previous data from our laboratory obtained by using a panel of transformed pre-B cell lines suggested that class II major histocompatibility complex and immunoglobulin gene expression may be controlled by distinct pathways in early B cells (30). We therefore undertook the study of the effects of LPS on one of the class II major histocompatibility complex genes, $\mathrm{A} \alpha$. Some information on the effect of LPS treatment on class II expression in B cells is available. Studies of the surface expression of Ia antigens in B cells after treatment with LPS has shown an apparent increase in surface expression which has been most convincingly documented at 36 to $64 \mathrm{~h}$ after treatment $(9,23,41)$. However, it has also been demonstrated that LPS treatment leads to an early and significant decrease in levels of mRNA for $A \alpha$ and $A \beta$ in murine spleen cells by $12 \mathrm{~h}$ (33).

The molecular mechanisms responsible for these effects are unknown. To study the early effects of LPS on class II gene expression and to compare these with the effects of LPS on immunoglobulin expression, the upstream region of the class II A $\alpha$ gene was examined. This 1.25-kilobase (kb) region has previously been shown by us to be active in cis in murine $B$ cells in a tissue-specific manner (5). Highly conserved transcriptional motifs called $X$ and $Y$ are present upstream of all class II genes sequenced to date. The conserved region containing these elements is found within bases -50 to -150 relative to the AUG initiator codon. The $\mathrm{X}$ motif is conserved and lies 19 to 21 base pairs (bp) upstream from the $Y$ motif. Studies with transgenic mice (11) have shown that the $\mathrm{X}$ and $\mathrm{Y}$ motifs are essential cis-acting elements for the transcription of class II genes. They are 
required for the accurate initiation of transcription in vivo and bind sequence-specific proteins. However, these sequences alone cannot account for the cis-activating effect of the 1.25-kb A $\alpha$ upstream region $(5,6)$.

In this report, we demonstrate the presence of an LPSinducible DNA-binding protein in nuclear extracts prepared from athymic (nu/nu) mouse splenocytes which binds to $\mathrm{A} \alpha$ sequences upstream of the X and Y motifs. Northern (RNA) blot analysis of splenic RNA confirmed previous dot blot analyses that LPS exposure results in a rapid reduction in $\mathrm{A} \alpha \mathrm{mRNA}$ which persists throughout the $18 \mathrm{~h}$ culture period. Within the culture period, there was increased binding of the LPS-inducible protein to two sites in the upstream regulatory region of the $A \alpha$ gene. Binding to each site was specifically inhibited by each of the two DNA fragments containing these sequences. A target sequence for binding was determined by DNase I footprint analysis, and an oligonucleotide corresponding to this region prevented binding. Although an NF-kB-like binding site is present within this target sequence, we have demonstrated that this site is not necessary for binding and that the true NF-kB target sequence does not inhibit binding. Thus, the LPSinducible protein which binds to the regulatory region of the class II $\mathrm{A} \alpha$ gene is not NF-кB.

\section{MATERIALS AND METHODS}

Cells and culture. Outbred nu/nu mice, 4 to 6 weeks old (obtained from R. Sedlacek, Massachusetts General Hospital, Boston), were killed by $\mathrm{CO}_{2}$ asphyxiation. Spleens were harvested sterilely and crushed in complete media consisting of RPMI 1640 supplemented with $5 \%$ heat-inactivated fetal bovine serum (catalog no. A-1111-L, lot no. 1111815; Hyclone Laboratories Inc.), $10 \mathrm{mM}$ HEPES ( $N$-2-hydroxyethylpiperazine- $N^{\prime}$-2-ethanesulfonic acid; Whittaker M. A. Bioproducts), $2 \mathrm{mM}$ glutamine, $0.1 \mathrm{mM} 2$-mercaptoethanol, and $100 \mathrm{U}$ of penicillin per $\mathrm{ml}$ and $100 \mu \mathrm{g}$ of streptomycin per $\mathrm{ml}$ (both from GIBCO Diagnostics). Hyclone serum and HEPES used in the complete media have negligible levels of LPS by assay. Media were tested by Chris Lu, Department of Medicine, Brigham and Women's Hospital, Boston, Mass., via the Limulus lysate assay (Cape Cod LEL Endotoxin Kit; Cape Cod Associates) and found to contain $<0.32$ ng of LPS per ml. Erythrocytes were lysed, and cells were washed with complete media, centrifuged, and suspended in complete media at a density of $2.5 \times 10^{6} / \mathrm{ml}$. For LPS stimulation, cell preparations were divided in half and cultured overnight in media alone or in media containing Escherichia coli LPS (Sigma Chemical Co.) to a final concentration of $50 \mu \mathrm{g} / \mathrm{ml}$. Cells were harvested for nuclear extract preparation after $18 \mathrm{~h}$ of overnight culture. Fluorescence-activated cell sorter analysis was performed on cells first incubated with a rat anti-Ia monoclonal antibody, M5/ 114 (14), followed by incubation with a fluorescein-conjugated goat anti-rat immunoglobulin $G$ reagent to assess stimulation of surface Ia with a FACS analyzer (Becton Dickinson and Co.) as previously described (31). The M5/114 monoclonal antibody detects polymorphic determinants on spleen cells from mice of $H-2$ haplotypes $b, d, q$, and $k$.

Nuclear extracts. Cells were harvested and washed in phosphate-buffered saline. Nuclear extracts (10) were prepared using $2 \times 10^{8}$ to $8 \times 10^{8}$ cells by a modification of the method of Dignam et al. as described elsewhere (6), except that the final salt concentration was adjusted to $0.5 \mathrm{M}$ to allow for lysis for $45 \mathrm{~min}$, centrifugation was at $150,000 \times g$ for $30 \mathrm{~min}$, and 3 to 4 volumes of buffer C (20 mM HEPES
[pH 7.9], $0.42 \mathrm{M} \mathrm{NaCl}, 1.5 \mathrm{mM} \mathrm{MgCl}_{2}, 0.2 \mathrm{mM}$ EDTA, 0.5 $\mathrm{mM}$ phenylmethylsulfonyl fluoride, $0.5 \mathrm{mM}$ dithiothreitol, $25 \%$ glycerol [ $\mathrm{vol} / \mathrm{vol}])$ per estimated cell volume was used.

DNA fragment and probe preparation. DNA fragments were prepared from a $B g / \mathrm{II}-S a c I$ upstream fragment of the $\mathrm{I}-\mathrm{A}_{\alpha}{ }^{\mathrm{k}}$ gene extending $1.9 \mathrm{~kb}$ upstream of exon $\mathrm{I}$ and cloned in the Bam HI and SacI sites of pUC18. The techniques used for fragment preparation, restriction digests, and gel sizing and separation were as described elsewhere (6). Probe DNA was 5 '-end labeled after treatment with calf alkaline phosphatase by $\mathrm{T} 4$ polynucleotide kinase in the presence of $\left[\gamma^{-32}\right.$ P]ATP $(3,000$ to $6,000 \mathrm{Ci} / \mathrm{mmol}$; Dupont, NEN Research Products). $3^{\prime}$-End labeling was performed with the Klenow fragment of DNA polymerase $I$ in the presence of $\left[\alpha{ }^{32} \mathrm{P}\right]$ ATP $(3,000 \mathrm{Ci} / \mathrm{mmol}$; NEN $)$ under standard conditions. Labeled DNA was extracted sequentially with phenolchloroform (1:1) and chloroform and separated on $5 \%$ polyacrylamide gels in $1 \times$ Tris-borate-EDTA. Unlabeled DNA fragments were used in competition experiments.

Oligonucleotides were synthesized on a synthesizer (Biosearch) by standard phosphoramidite techniques. Overnight deprotection for 8 to $12 \mathrm{~h}$ was accomplished with fresh ammonium hydroxide at $55^{\circ} \mathrm{C}$. After being vacuum dried and washed in sterile distilled water, $100 \mu \mathrm{g}$ of single-stranded DNA was loaded on an $8 \mathrm{M}$ urea denaturing gel $(12 \%$ polyacrylamide). DNA bands were visualized by UV shadowing, cut and eluted overnight in $0.5 \mathrm{M} \mathrm{NaCl}-10 \mathrm{mM}$

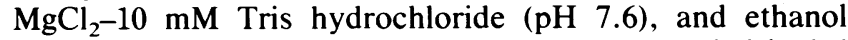
precipitated. Complementary strands were annealed in 0.6 M NaCl-20 mM Tris hydrochloride ( $\mathrm{pH}$ 7.6)-1 mM EDTA by heating them to $95^{\circ} \mathrm{C}$ for $5 \mathrm{~min}$, placing them in $65^{\circ} \mathrm{C}$ for $5 \mathrm{~min}$, and cooling them to room temperature over 3 to $4 \mathrm{~h}$. Annealed oligonucleotides were ethanol precipitated in the presence of $10 \mathrm{mM} \mathrm{MgCl}$. For Northern blot hybridization, probes were an agarose gel-purified cDNA fragment of 1.0 $\mathrm{kb}$ for $\mathrm{A} \alpha$ and a 1.1-kb fragment of A50 cDNA (25). These probes were labeled by nick translation (34) with $\left[\alpha-{ }^{32} \mathrm{P}\right]$ $\operatorname{dCTP}(3,000 \mathrm{Ci} / \mathrm{mmol}$; NEN $)$.

DNA-binding (mobility shift) assays. DNA-binding assays were performed as described elsewhere (6). Nuclear extracts were incubated with equal volumes of sterile water or competitor DNA at room temperature for $5 \mathrm{~min}$. The remainder of the reaction components, including labeled fragments, were then added, with optimal poly $(\mathrm{dI}-\mathrm{dC}) \cdot(\mathrm{dI}-\mathrm{dC})$ concentration being $0.33 \mathrm{mg} / \mathrm{ml}$ in a $12-\mu l$ reaction, and incubated for $20 \mathrm{~min}$. Samples were run on $4 \%$ polyacrylamide gel electrophoresis in $45 \mathrm{mM}$ Tris-borate-1 mM EDTA at $200 \mathrm{~V}$ with cooling. Gels were then dried under vacuum, and autoradiography was performed. Nuclear extracts were normalized for protein concentration, and equal amounts of protein, usually 0.5 to $1.5 \mu \mathrm{g}$, were added within experiments.

DNase I footprint analysis. DNA-binding reactions were performed as described above but were proportionally scaled up to a 25 - to $30-\mu$ l volume in each of five lanes. Optimal DNase I concentration was determined by concentration curves and was found to be $2 \mu \mathrm{g} / \mathrm{ml}$ for the fragment II probes. Fragments were labeled at the $3^{\prime}$ and $5^{\prime}$ ends in separate experiments, and 500,000 Cerenkov cpm was used per total reaction. After standard incubation to allow binding, $3 \mu \mathrm{l}$ of $50 \mathrm{mM} \mathrm{MgCl}{ }_{2}-50 \mathrm{mM} \mathrm{CaCl}_{2}$ was added, with the subsequent addition of $37^{\circ} \mathrm{C}$-activated DNase I. Samples were incubated for $90 \mathrm{~s}$ at room temperature, quenched with EDTA and EGTA [ethylene glycol-bis( $\beta$-aminoethyl ether)$N, N, N^{\prime}, N^{\prime}$-tetraacetic acid] to $5 \mathrm{mM}$ each and subjected to $4 \%$ polyacrylamide gel electrophoresis in $45 \mathrm{mM}$ Tris-bo- 


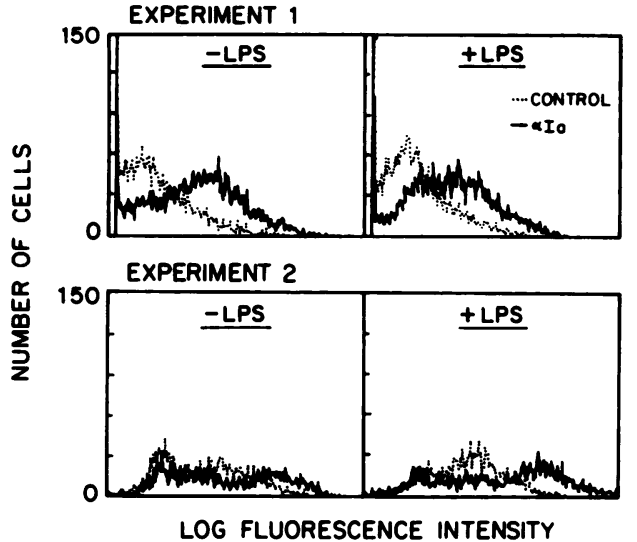

FIG. 1. FACS analysis of whole-spleen preparations from athymic mice with and without exposure to LPS at $50 \mu \mathrm{g} / \mathrm{ml}$. Control antibody is fluorescein-conjugated goat anti-rat immunoglobulin G. Anti-Ia antibody was M5/114, a monoclonal rat anti-Ia antibody (14). Cell surface staining was performed after $18 \mathrm{~h}$ of culture. Experiment 1 shows no induction of surface Ia with LPS exposure, as was seen in two of seven experiments. Experiment 2 shows a modest induction of surface Ia, as was seen in five of seven experiments.

rate-1 mM EDTA. Free and bound bands, identified by autoradiography of wet gels, were cut from the gels and eluted by diffusion. DNA was purified on Elutips columns (Schleicher \& Schuell) and ethanol precipitated. Products of DNase I digestion were resolved on $6 \%$ polyacrylamide-8 $\mathrm{M}$ urea linear and wedge sequencing gels. An equal number of radioactive counts were loaded in each free and bound lane. Maxam-Gilbert ladders of unreacted probe were run simultaneously in order to identify sequences (13).

RNA analysis. In timed experiments, all cultures were maintained for a total of $18 \mathrm{~h}$, regardless of treatment. Total cellular RNA was harvested from nu/nu mouse spleen cells by the guanidine isothiocyanate-cesium chloride density gradient method of Chirgwin et al. (8). Agarose gels (1.3\%) containing $0.22 \mathrm{M}$ formaldehyde were used for size fractionations. RNA was transferred in $20 \times \mathrm{SSC}(1 \times \mathrm{SSC}$ is $0.15 \mathrm{M}$ $\mathrm{NaCl}$ plus $0.015 \mathrm{M}$ sodium citrate) to Nytran filters as described elsewhere (8). Northern blots were prehybridized for $2 \mathrm{~h}$ at $42^{\circ} \mathrm{C}$ in $48 \%$ formamide $-5 \times$ SSC $-10 \mathrm{mM}$ Tris $-0.1 \%$ sodium dodecyl sulfate-1 $1 \times$ Denhardt solution- $10 \%$ dextran sulfate-100 $\mu \mathrm{g}$ of denatured sheared herring sperm DNA per $\mathrm{ml}$. Hybridization was for $36 \mathrm{~h}$ under identical conditions with the addition of $100 \mu \mathrm{g}$ of herring sperm DNA and $1 \times$ $10^{6}$ to $3 \times 10^{6} \mathrm{cpm}$ of nick-translated cDNA probe per ml of final volume. Duplicate filters were hybridized to either $\mathrm{A} \alpha$ probe or A50 probe. Filters were washed twice for $30 \mathrm{~min}$ each in $2 \times$ SSC $-0.1 \%$ sodium dodecyl sulfate at room temperature and then twice for $30 \mathrm{~min}$ each at $65^{\circ} \mathrm{C}$ in $0.2 \times$ SSC $-0.1 \%$ sodium dodecyl sulfate. Autoradiography was performed on wet filters. Filters were then washed under conditions to remove bound probe and rehybridized to the second probe.

\section{RESULTS}

LPS treatment minimally affects surface Ia expression and decreases level of Ia mRNA at early time points. Figure 1 shows representative results of FACS analysis experiments on expression of surface Ia antigens in whole-spleen preparations from athymic mice with and without LPS exposure at $18 \mathrm{~h}$. These mice are maintained through life in a germfree

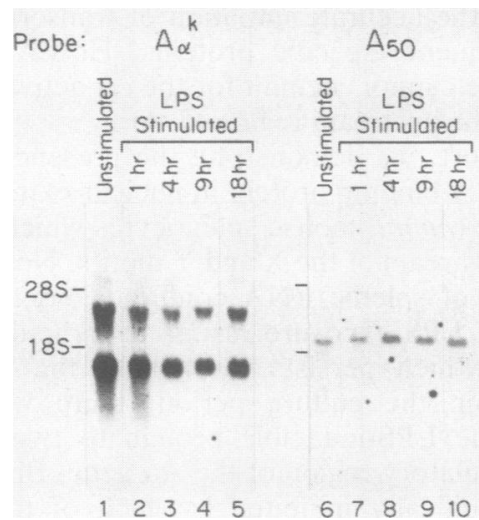

FIG. 2. Northern blot analysis of the time course of LPS effect on A $\alpha$ mRNA. Total cellular RNA was harvested from splenic lymphocytes of athymic mice after being cultured with $50 \mu \mathrm{g} / \mathrm{ml}$ of LPS for $1 \mathrm{~h}$ (lanes 2 and 7), $4 \mathrm{~h}$ (lanes 3 and 8), $9 \mathrm{~h}$ (lanes 4 and 9), and $18 \mathrm{~h}$ (lanes 5 and 10). Total culture time for all samples was 18 $\mathrm{h}$. Unstimulated spleen cells cultured for $18 \mathrm{~h}$ (lanes 1 and 6) served as control. Total RNA (10 $\mu \mathrm{g}$ per lane, as measured by optical density at $260 \mathrm{~nm}$ ) was used to prepare duplicate Northern blots which were hybridized to either A $\alpha$ probe or A50 probe. Rehybridization of the same filters with the second probe confirmed these results.

environment and thus are protected at baseline from exposure to endotoxin. In addition, athymic mice are $\mathrm{T}$-cell deficient, and splenic lymphocytes are thus predominantly B cells. Flasks stimulated with LPS $(50 \mu \mathrm{g} / \mathrm{ml})$ were examined microscopically after $18 \mathrm{~h}$, and blast formation was present in all experiments. Although other investigators have shown an early two- to threefold increase in surface Ia antigen expression after treatment with LPS (9), we have seen a very modest increase in surface Ia expression at $18 \mathrm{~h}$ in five of seven experiments and no increase in expression in two experiments. One experiment from each group is shown. Since the FACS data are not normalized for the increase in cell surface area produced by LPS treatment, these data suggest that at early time points of stimulation, LPS is not a positive regulator of Ia expression.

Dot blot analysis of spleen cells treated with LPS (25 $\mu \mathrm{g} / \mathrm{ml}$ ) for up to $12 \mathrm{~h}$ has suggested that such treatment leads to a decrease in mRNA encoding Ia proteins (33). We performed Northern blot analyses of total RNA from stimulated and unstimulated spleen cells (Fig. 2). RNA was prepared from cells incubated with LPS for $1,4,9$, and $18 \mathrm{~h}$. Filters were probed with A $\alpha$ cDNA and A50 cDNA probes. A50 contains sequences for a constitutively expressed mRNA (25) and serves as a control for sample concentration. Northern blot analysis demonstrated that treatment with LPS reduces the level of mature $A \alpha$ mRNA in comparison with unstimulated controls. Decrease in mRNA began by $1 \mathrm{~h}$ (Fig. 2, lane 2), continued at $4 \mathrm{~h}$, and was maximal by $9 \mathrm{~h}$. At $18 \mathrm{~h}$, mRNA levels remained substantially reduced in comparison with unstimulated controls. Densitometry demonstrated a reduction in $\mathrm{A} \alpha \mathrm{mRNA}$ from baseline to $52 \%$ of baseline at $1 \mathrm{~h}, 23 \%$ of baseline at $4 \mathrm{~h}, 19 \%$ of baseline at 9 $\mathrm{h}$, and $22 \%$ of baseline at $18 \mathrm{~h}$. Levels of both mature $\mathrm{A} \alpha$ mRNA and a larger presumed $A \alpha$ precursor mRNA were reduced. Hybridization of a duplicate filter and rehybridization of the same filter to the A50 cDNA probe indicate that A50 mRNA concentrations were comparable among samples and did not bias the results. In addition, levels of A50 mRNA 
have remained constant with LPS stimulation. We conclude that the level of $A \alpha$ mRNA decreased with LPS treatment.

An LPS-inducible DNA-binding protein binds to an $\mathrm{A \alpha}$ upstream sequence containing an NF-KB-like binding site. To begin to examine the mechanism of LPS effects on class II gene expression, we sequenced $1.23 \mathrm{~kb}$ of DNA of the upstream regulatory region of $\mathrm{A}_{\alpha}{ }^{k}$. Figure 3 shows this sequence, with the sequencing strategy shown below. The $X$ and $Y$ consensus motifs are noted just upstream of the ATG start codon. A reverse CCAAT box motif is also demarcated within the $Y$ box region. Of note is the absence of a TATA box, as has been described in the upstream regions of other genes (7). A DNA-binding protein whose binding activity is influenced both by IL- 4 and by differentiation in B cells has been described (5). The DNA sequences bound by this protein, BRE-1 and BRE-2, are noted. Of interest is that just upstream of BRE-2 is the sequence AAGGGAATTTTCC (Fig. 3A), which has a $10 / 12$ sequence homology to the known binding site of NF-kB, an LPS-inducible DNAbinding protein specific for the immunoglobulin $\kappa$ gene enhancer and regulatory for $\kappa$ light chain transcription in $B$ cells $(37,38)$.

Since the control of gene transcription is usually mediated by trans-acting transcriptional factors which bind to upstream regulatory elements, we assayed nuclear extracts from unstimulated and LPS-stimulated splenic preparations from athymic mice for binding to seven DNA fragments prepared by Hinfl digestion of $1.9 \mathrm{~kb}$ from the upstream regulatory region of $A_{\alpha}{ }^{k}$ (Fig. 4A). Equal portions of unstimulated and stimulated extracts were added to each radiolabeled HinfI fragment and assayed for binding activity by mobility shift assays (Fig. 4B). All fragments were assayed, including fragment IV, which contains the $X-Y$ consensus sequence region. Binding to fragment IV occurs in both unstimulated and stimulated extracts (Fig. 4B, lanes 11 and 12 ) and represents constitutive binding to the $X$ box and $Y$ box motifs (6). This binding activity is equivalent in induced and uninduced spleen cells and serves as a control for protein concentration. Retarded bands representing DNAprotein complexes were present in LPS-induced extracts when restriction fragments I and II (Fig. 4B, lanes 3 and 6) were assayed with splenic nuclear extract. Binding activity was seen at low level in the uninduced extracts (Fig. 4B, lanes 2 and 5) but was present in much greater amounts in LPS-induced extracts. Treatment of extract with proteinase $\mathrm{K}$ abolished the DNA-protein complex (results not shown). These results demonstrate the presence of an LPS-inducible DNA-binding protein which binds to two sites in the upstream regulatory region of $A_{\alpha}{ }^{k}$.

To demonstrate specificity of protein binding to these $A_{\alpha}{ }^{k}$ regions, unlabeled competitor fragments were prepared from cloned, truncated subfragments of fragments I and II: $I(t)$ and II(t) (Fig. 4A) (5). Mobility shift assays were performed after a 5-min preincubation with excess unlabeled competitor DNA (Fig. 5). Unlabeled fragment $I(t)$ prevented the formation of a retarded complex when incubated with nuclear extract and radiolabeled fragment I (Fig. 5, lanes 3 and 11). Unlabeled unrelated competitor fragments did not prevent binding (Fig. 5, lanes 5 and 13), demonstrating that the protein binding is specific for fragment I. Unlabeled II(t) also prevented protein binding to radiolabeled fragment II (Fig. 5, lanes 8 and 16), but unrelated competitor DNA fragments did not (lanes 9 and 17). In addition, cross-competition occurred when unlabeled II(t) was used as a competitor for binding to fragment I (Fig. 5, lane 12) and when $I(t)$ was used as competitor for binding to fragment II (lane 15). Because

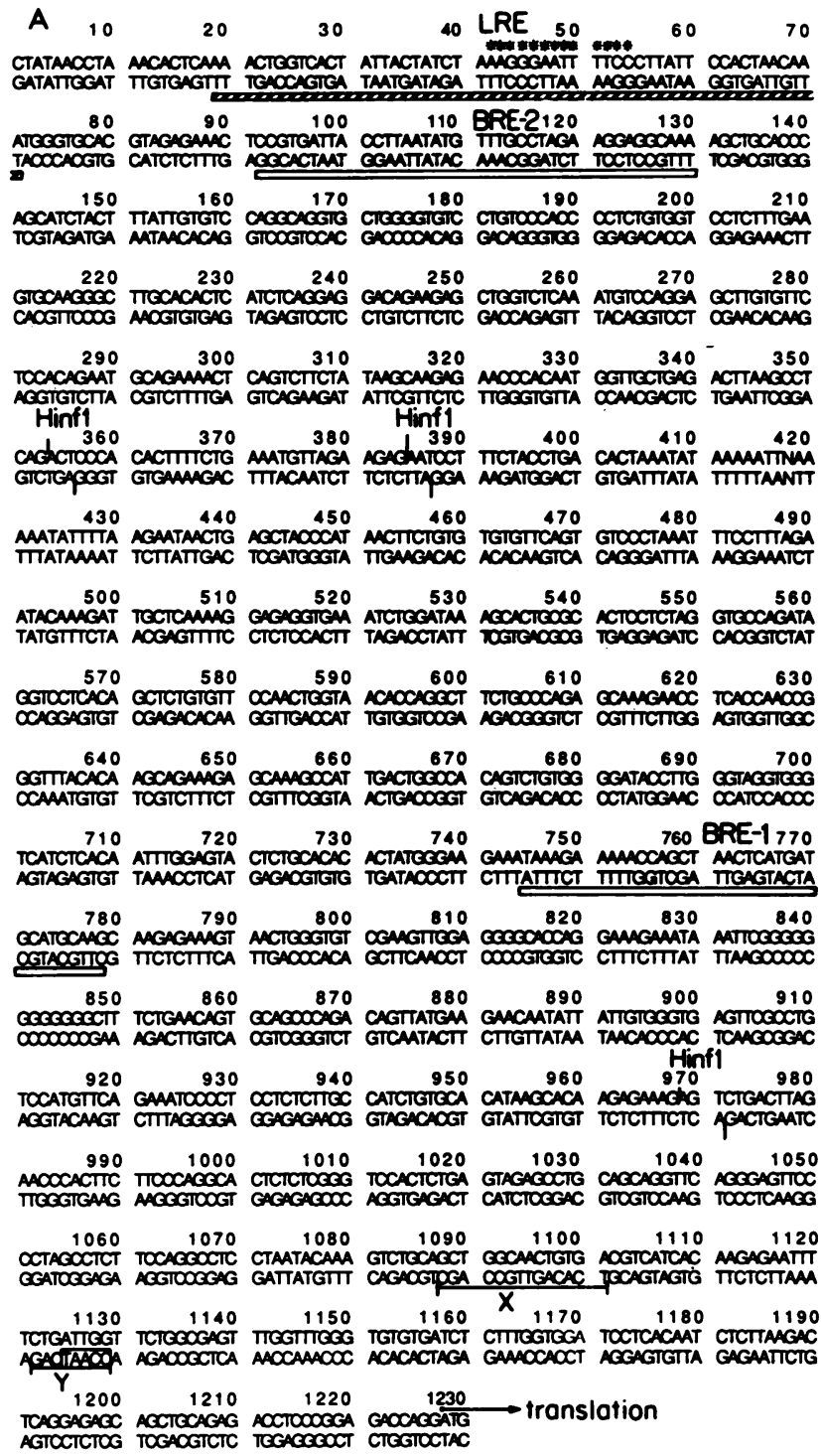

B

0
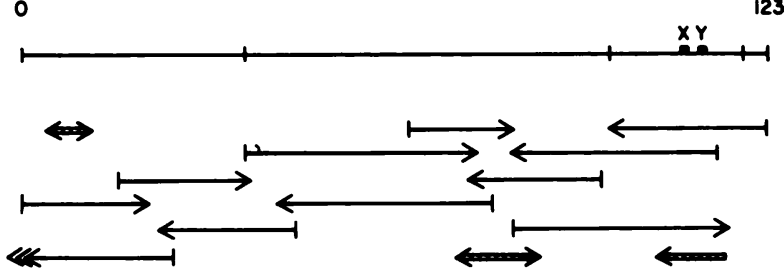

FIG. 3. (A) Sequence of $1.23 \mathrm{~kb}$ of DNA of the upstream regulatory region of $\mathrm{A}_{\alpha}{ }^{\mathrm{k}}$. Hinfl restriction sites are noted by vertical bars. The target sequence of the LPS-induced DNA-binding protein is designated by the cross-hatched bar. The target sequences of the previously described (5) IL-4-responsive elements (BRE-1 and BRE-2) are designated by open bars. The NF- $\mathrm{BB}$-like sequence is starred. $\mathrm{X}$ and $\mathrm{Y}$ boxes are indicated. Note that there is a reverse CCAAT box motif located within the $\mathrm{Y}$ box, but there is no TATA box in the upstream sequence. Numbering is arbitrarily designated as 0 through 1230, since the actual site of initiation of transcription has not been determined. (B) Sequencing strategy. Both strands were sequenced by the Sanger dideoxy method with some overlap from Maxam-Gilbert ladders. This sequence has been submitted to GenBank and assigned accession number M24602. 


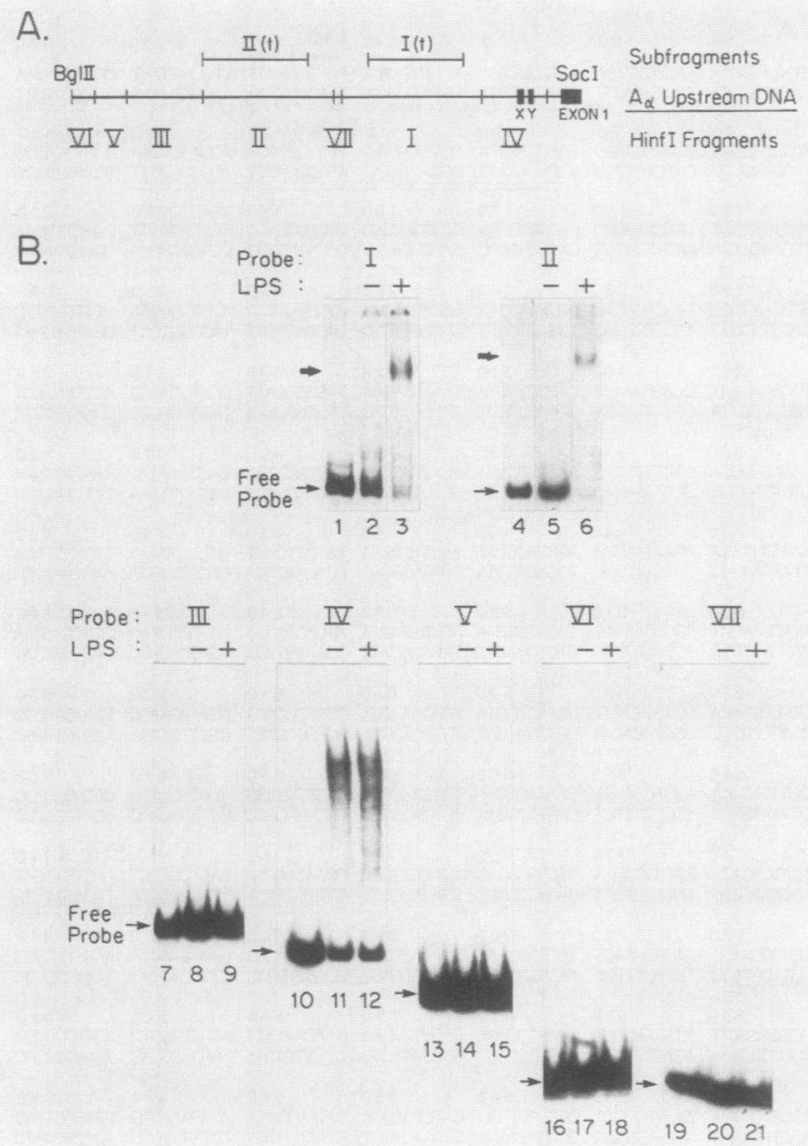

FIG. 4. (A) Schematic representation of the Hinfl restriction digest of the upstream region of A $\alpha$. Hinfl sites are marked with vertical hatches. Fragments are numbered according to size. Solid boxes identify the conserved $\mathrm{X}$ and $\mathrm{Y}$ box consensus sequences within fragment IV and the translation initiation of exon I leader peptide to the right. I(t) and II $(t)$ denote the positions of cloned truncated subfragments of fragments I and II. (B) Mobility shift assays of unstimulated and LPS-stimulated extracts to fragments I through VII. Unstimulated ( - ) and LPS-stimulated $(+)$ extracts are shown in pairs. Equal portions of extract were added to radiolabeled Hinfl fragments from the upstream region of the $\mathrm{A}_{\alpha}{ }^{\mathrm{k}}$ gene. Lanes 1 , $4,7,10,13,16$, and 19 contain no added nuclear extract. Retarded bands are present when LPS-induced extracts are incubated with fragments I and II (lanes 3 and 6) but not when they are incubated with other fragments. Binding to fragment IV (lanes 11 and 12) represents the constitutive $\mathrm{X}$ and $\mathrm{Y}$ box binding-protein activity which is present in all splenic nuclear extracts and serves as a control for protein concentration.

these cross-competition data implied that the same protein(s) binds to fragments I and II, and because the closest match to an NF-kB target sequence was present in the fragment II DNA, we chose to focus on this fragment to identify the region of protein binding.

A target sequence of the LPS-inducible binding protein is identified. To determine the target sequence of the LPSinduced binding protein, we performed DNase I footprint analysis (13) using the fragment II(t) subfragment of fragment II. Fragment II(t) was labeled on both the coding and noncoding strands in separate experiments. DNA-protein complexes were formed and subjected to DNase I digestion. Radiolabeled bands representing free and complexed DNA were cut from the gel, eluted, and run in parallel on denaturing polyacrylamide gels. One distinct region of altered

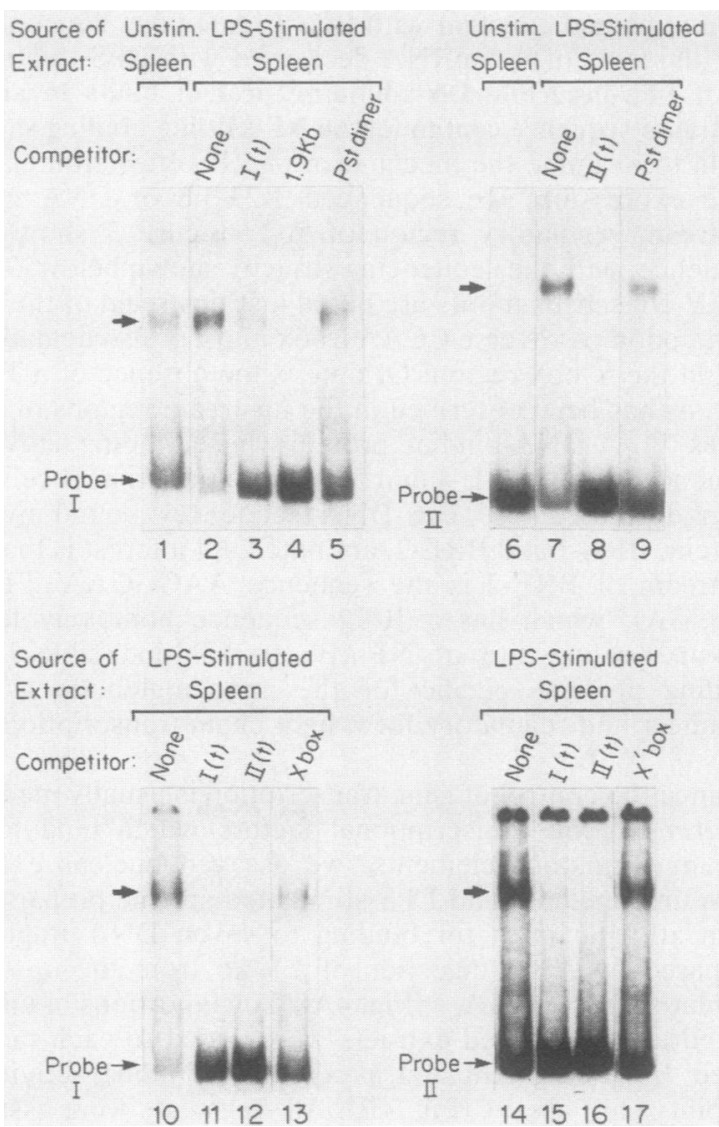

FIG. 5. Competition and cross-competition experiments. LPSinduced nuclear extracts were incubated with radiolabeled fragment I (lanes 2 through 5 and 10 through 13) and fragment II (lanes 7 through 9 and 14 through 17). Lanes 1 and 6 contain unstimulated nuclear extract. Lanes 2, 7, 10, and 14 contain LPS-stimulated extract without competitor. Competitor fragments are I(t) (lanes 3, 11, and 15), 1.9-kb upstream fragment (lane 4), dimerized Pst fragment from fragment IV (lanes 5 and 9), fragment II(t) (lanes 8, 12 , and 16), $A \alpha X$ box plus flanking sequence (44 bp) (lane 13), and randomly scrambled sequence of $27 \mathrm{bp}$ from $\mathrm{DR} \alpha \mathrm{X}$ box ( $\mathrm{X}^{\prime}$ box) (lane 17). All competitor fragments were added in molar excess at 50 ng.

reactivity was consistently identified in fragment $\mathrm{II}(\mathrm{t})$ between free and protein-bound DNA in separate experiments (Fig. 6A). Binding of the LPS-induced protein to the noncoding strand produced three distinct hypersensitive sites. In the complementary region of the coding strand, binding of the LPS-induced protein led to a modest decrease in reactivity in the central portion of this complementary region. This decrease was seen reproducibly in three separate experiments. We have designated this region the LPSresponsive element (LRE). Additional attempts to obtain footprints by using the nuclease activity of 1,10-phenanthroline-copper ion (19) revealed no altered reactivity of bases in bound compared with free DNA (results not shown). Of interest is that in two of the three experiments with DNase I digestion, modest protection was also seen on the coding strand in the previously described B-cell-responsive element (BRE-2) (Fig. 6). This region, BRE-2 (5), represents a target sequence of a previously described IL-4-inducible DNAbinding protein, active at low levels in nuclear extracts from untreated spleen cells. The relative locations of the binding sites of the LPS-inducible and IL-4-inducible DNA-binding proteins are shown in Fig. 6B. 


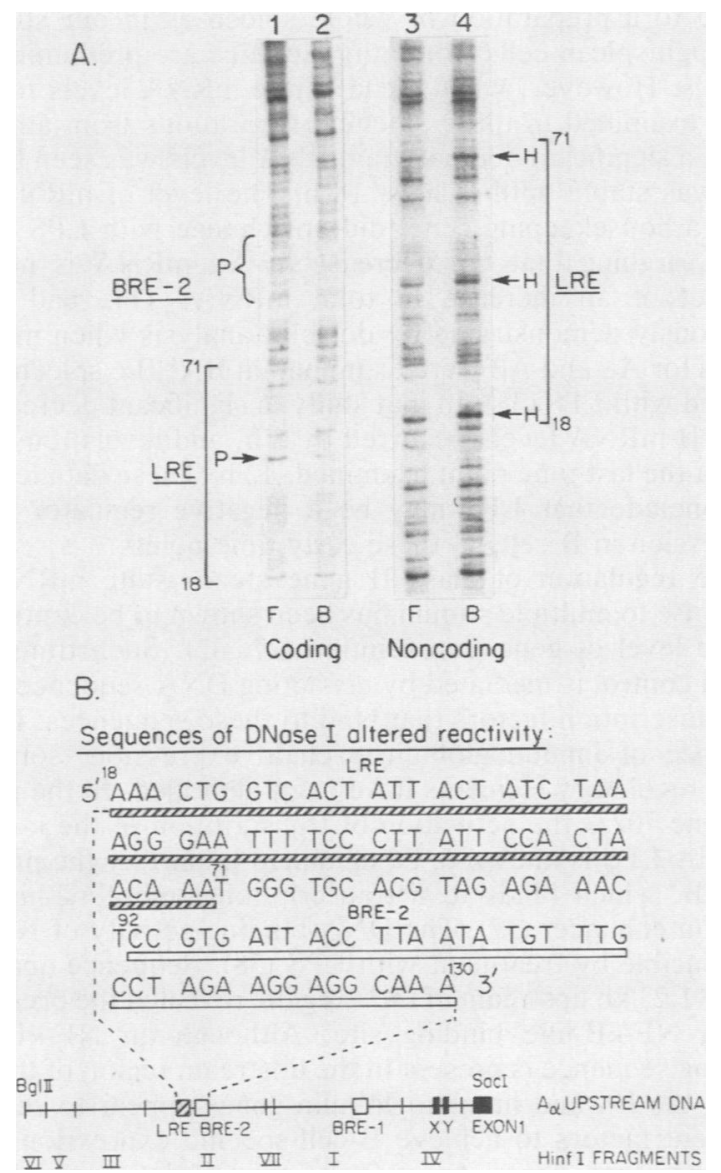

FIG. 6. (A) DNase I footprint of coding and noncoding strands. Free and bound bands generated from DNA-binding gel assays were purified on nondenaturing polyacrylamide gels after digestion with DNase I. Maxam-Gilbert sequence reactions were performed on labeled probe DNA, and the products were coelectrophoresed. Lanes 1 and 2, DNA from the coding strand: lanes 3 and 4. DNA from the noncoding strand. $\mathrm{F}$ and $\mathrm{B}$. Cleavage products of unbound (F) and complexed (B) DNA. H, Areas of hypersensitivity: P. areas of protection. Hypersensitive sites span the LRE (bases 18 to 71 , as numbered in Fig. 3). The lower $P$ falls in the LRE sequence (bases 18 to 71), while the upper P falls in BRE-2 (5). (B) Schematic representation of the upstream region of $A \alpha$. Hinfl sites are marked with verticle hatches. Solid boxes labeled $X$ and $Y$ identify conserved $\mathrm{X}$ and $\mathrm{Y}$ box consensus sequences within fragment IV. Open box in fragment I identifies the previously defined BRE-1. Open box in fragment II identifies the previously defined BRE-2, with sequence shown above. Cross-hatched box shows newly defined LRE, with sequence shown above.

To confirm that the region identified as the LRE was in fact the site of protein binding, a 53-bp oligonucleotide corresponding to this region was synthesized (Fig. 6B) and used in competition experiments (Fig. 7). Protein binding (Fig. 7, lane 1) was partially prevented by $25 \mathrm{ng}$ of oligonucleotide (lane 2) and was completely prevented by $50 \mathrm{ng}$ (lane 3) and $100 \mathrm{ng}$ (lane 4). Two distinct unrelated competitor oligonucleotides of similar lengths did not prevent binding at $100 \mathrm{ng}$ (Fig. 7, lane 5) and $50 \mathrm{ng}$ (data not shown) in four parallel experiments. One competitor contained randomly scrambled sequence from the $\mathrm{X}$ box of $\mathrm{DR} \alpha\left(\mathrm{X}^{\prime}\right.$ box $)$. whereas the second contained sequence from the $X$ box of the DQ $\beta$ gene. The 53-bp LRE oligonucleotide was also able to prevent binding to radiolabeled fragment $\mathrm{I}$, giving further

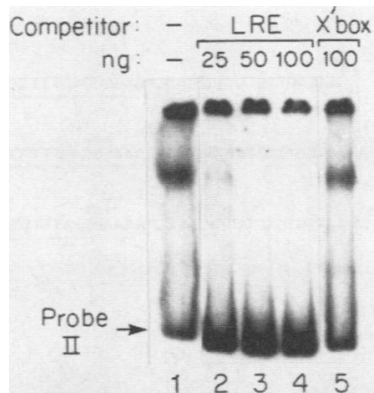

FIG. 7. Competition experiments with LRE. LPS-induced nuclear extracts were incubated with radiolabeled fragment II without (lane 1) and with (lanes 2 through 5) competitor. Lanes 2 through 4, Preincubation with the 53-bp LRE oligonucleotide spanning the protected region at 25,50 , and $100 \mathrm{ng}$, respectively; lane 5, preincubation with an unrelated oligonucleotide, $\mathrm{X}^{\prime}$ box, containing randomly scrambled sequence from the $\mathrm{X}$ box of $\mathrm{DR} \alpha$ at $100 \mathrm{ng}$.

evidence that the same protein is binding to both fragments. Therefore, we conclude that the protected region, LRE, identified by DNase I footprinting, is a target site of specific binding by the LPS-inducible DNA-binding protein. The previously identified NF-кB-like target sequence is present within this LRE.

The LPS-inducible DNA-binding protein is distinct from NF-кB. The presence of the NF-kB-like sequence within the target binding site of this LPS-inducible protein was consistent with the possibility that this protein may be NF-кB. To test this possibility, a 53-bp oligonucleotide containing the true NF- $\mathrm{B}$ site flanked by the $\kappa$ enhancer sequences identified by Picard and Schaffner (29) was synthesized and used in competition experiments (Fig. 8B). The immunoglobulin $\mathrm{NF}-\kappa \mathrm{B}$ target sequence at 25,50 , and $100 \mathrm{ng}$ (Fig. 8B, lanes 3 through 5 , respectively) was unable to prevent binding to fragment II probe, compared with a control reaction without competitor DNA (lane 2). To further demonstrate that the LPS-inducible $A \alpha$ DNA-binding protein was not NF- $\mathrm{B}$, an additional 53-bp oligonucleotide was prepared from the LRE target sequence in the $\mathrm{A}_{\alpha}{ }^{\mathrm{k}}$ upstream region. This oligonucleotide contained mutations in the three key $G$ residues (Fig. 8A), identified by Sen and Baltimore (37), which are required for binding by NF-кB $(2,39)$. Despite these mutations, this oligonucleotide prevented binding to fragment II at 25, 50, and $100 \mathrm{ng}$ (Fig. 8B, lanes 6 through 8, respectively). Control oligonucleotides did not inhibit complex formation (Fig. 8B, lanes 10 and 11), whereas the LRE oligonucleotide did so (lane 9). Identical results were obtained when competition experiments were performed with radiolabeled fragment I (data not shown). Therefore, we conclude that this LPSinducible DNA-binding activity is not NF-кB.

\section{DISCUSSION}

Cells of the B lineage progress through known development stages, from bone-marrow-derived stem cells, to pre-B cells, to mature $B$ cells able to secrete immunoglobulin, and finally to plasma cells. The expression of Ia in B cells is determined both by the B-cell developmental stage and by certain external stimuli. Treatment of pre-B cells with LPS is known to induce their differentiation into immunoglobulinsecreting B cells (24). Previous data from our laboratory have suggested that class II (Ia) antigen and immunoglobulin gene expression may be controlled by distinct pathways in early B cells (30). We therefore undertook to study the 
A

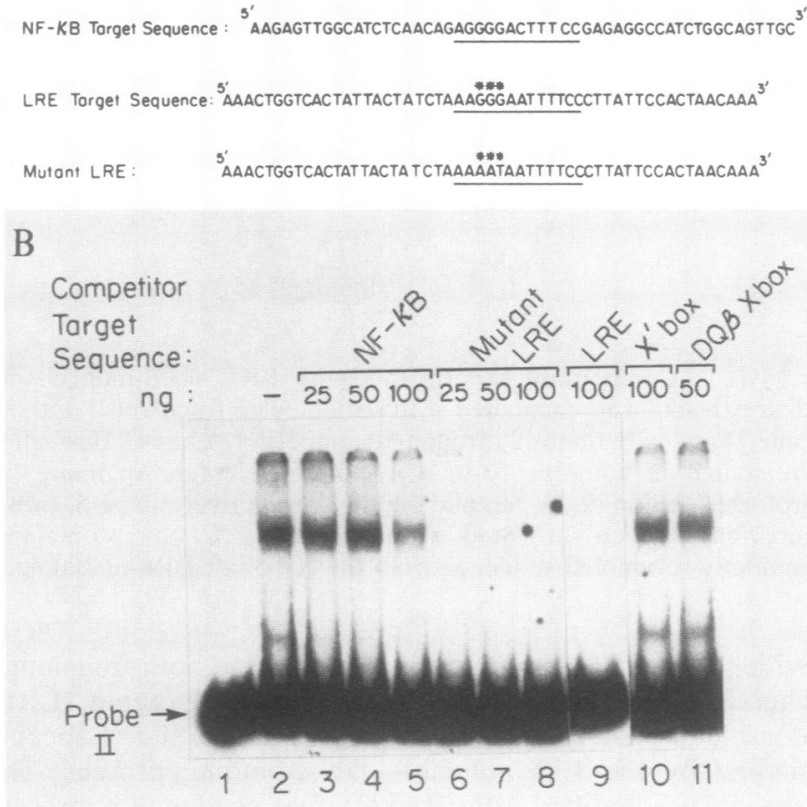

FIG. 8. Binding competition assay with NF-кB target sequence and oligonucleotides. (A) Oligonucleotide sequences used in competition assays. Note that the mutant LRE oligonucleotide has mutations in three key $G$ residues. (B) Lane 1 , Radiolabeled fragment II probe alone; lanes 2 through 11, LPS-induced nuclear extracts without (lane 2) and with (lanes 3 through 11) competitor. Lanes 3 through 5, True NF-kB target sequence at 25,50 , and 100 ng, respectively; lanes 6 through 8 , mutant oligonucleotide spanning the LRE; lane 9, true LRE; lane 10, 27-bp oligonucleotide comprising the randomly scrambled sequence from the $\mathrm{X}$ box of $\mathrm{DR} \alpha\left(\mathrm{X}^{\prime}\right.$ box); lane 11 , a second unrelated oligonucleotide spanning the DQ $\beta$ $\mathrm{X}$ box.

effects of LPS on expression of class II (Ia) antigen in cells of the $B$ lineage.

The final effect of LPS-treatment of B cells on the surface expression of Ia antigens is undoubtedly complex. Several investigators have shown an increase in surface Ia expression after treatment with LPS. This effect appears to be cell cycle dependent and is probably most pronounced at 36 to 48 $\mathrm{h}$ (23), although some investigators have seen this effect as late as 64 to $84 \mathrm{~h}(41)$. In a purified B-cell population, Dennis et al. (9) have demonstrated an approximately twofold increase in surface Ia after treatment with LPS as early as 9 h. However, the increase in cell size and thus in cell surface area was not accounted for, raising the possibility that the number of Ia molecules per unit surface area was not increased at this early time point. The FACS data obtained in our laboratory demonstrate no substantial increase in surface Ia expression at $18 \mathrm{~h}$. No increase in surface Ia expression was seen in two of seven experiments in splenic preparations from athymic mice, and only a modest increase was seen in five of seven experiments at $18 \mathrm{~h}$. Furthermore, if the increase in surface area of LPS blasts is accounted for, there may be no significant change in the density of surface Ia antigen expression in whole spleens from athymic mice after $18 \mathrm{~h}$ of LPS stimulation. In contrast, IL-4 treatment of athymic mouse spleen preparations led to a significant increase in surface Ia expression in our hands (data not shown).

It is possible that some of this discrepancy is due to the difference in examining a purified B-cell population as op- posed to a preparation of whole spleen as in our studies, although spleen cells from athymic mice are predominantly B cells. However, when steady-state mRNA levels for A $\alpha$ were examined in these splenic preparations from athymic mice, a significant decrease in mRNA levels was seen by $4 \mathrm{~h}$ and was stable until at least $18 \mathrm{~h}$. The level of mRNA for A50, a housekeeping gene, did not change with LPS treatment, arguing that the decrease in A $\alpha$ mRNA is not an artifact of an increase in total mRNA. This had been previously demonstrated by dot blot analysis when mRNA levels for $A \alpha$ and $A \beta$ were examined in BALB/c spleen cells treated with LPS (33). In that study, a significant decrease in class II mRNA levels occurred by $5 \mathrm{~h}$, and levels remained low at the last time point examined, $12 \mathrm{~h}$. These data lead us to conclude that LPS may be a negative regulator of Ia expression in B cells at these early time points.

The regulation of class II gene steady-state mRNA in response to multiple stimuli has been shown to be controlled at the level of gene transcription $(27,32)$. Such transcriptional control is mediated by cis-acting DNA sequences and by transcription factors that bind to these sequences. In the instance of immunoglobulin $\mathrm{k}$-chain expression, some of these regulatory elements have been identified. In the pre-B cell line $70 \mathrm{Z} / 3$ the activation of transcription of the $\kappa$-chain gene by LPS is known to be mediated in part by the protein $\mathrm{NF}-\kappa \mathrm{B}$, which binds to a transcriptional motif within the $\kappa$-chain enhancer (37). The DNA-binding activity of NF-KB is inducible by treatment with LPS (38). Sequence analysis of the $1.23 \mathrm{~kb}$ upstream of the A $\alpha$ gene revealed the presence of an NF-кB-like binding site. Although an NF-kB-like binding sequence is present in the upstream region of the $\mathrm{E} \alpha$ gene, the $\mathrm{E} \alpha$ and immunoglobulin genes appear to rely on different factors to achieve B-cell-specific expression (12). We therefore chose to examine unstimulated and LPSstimulated nuclear extracts from spleen preparations from athymic mice, which consist predominantly of B cells, in order to identify a nuclear factor analogous or identical to NF- $\mathrm{kB}$ which may bind to the upstream regulatory region of a class II (Ia) gene, A $\alpha$.

In the present report we demonstrate the presence of an LPS-inducible DNA-binding protein in nuclear extracts prepared from splenic preparations from athymic mice. This LPS-inducible protein binds to two fragments prepared from the upstream regulatory region of $A_{\alpha}{ }^{k}$, and these fragments cross-compete for binding. By using DNase I footprint analysis, a target binding sequence was identified in fragment II of the Hinfl digest of the upstream regulatory region of $A_{\alpha}{ }^{k}$. An oligonucleotide synthesized from this LRE successfully competes for binding to fragment II. Located within the target binding site of the LPS-inducible protein is a nucleotide sequence with a 10/12 homology to the binding site of the known LPS-inducible B-cell protein, NF-кB. Recent studies on transcription factors provide evidence that a factor which serves as an activator of gene expression can function as a repressor of gene expression when bound to a somewhat different target sequence (16). This raised the possibility that the LPS-inducible protein binding to be upstream region of $A \alpha$ might be NF-kB even though NF-kB acts as a positive regulator in pre-B cells. However, an oligonucleotide containing the true NF-kB binding site was unable to compete for binding. In addition, three $G$ residues which are essential for the binding of NF- $\mathrm{B}$ have been identified (37). When the three $G$ residues present in our NF-kB-like sequence were mutated from GGG to AAT, the mutated oligonucleotide was still able to prevent binding, suggesting that these $G$ residues are not essential for the 
binding of this protein. These data strongly suggest that this LPS-inducible protein is distinct from NF- $\mathrm{BB}$. Therefore, LPS leads to the induction of two distinct DNA-binding proteins in cells of the $B$ lineage, one binding to a site in the $\kappa$-chain enhancer, NF- $\mathrm{B}$, and acting as a positive regulator, and one binding upstream of an Ia gene, which we postulate may be a negative regulator. This provides further evidence for the hypothesis that B-cell expression of class II and immunoglobulin genes proceeds along distinct pathways.

Taken together, these data demonstrate that the LPSinducible DNA-binding protein is distinct from NF-KB and binds to $A \alpha$ upstream gene sequences. They further suggest that this LPS-inducible protein may be a factor in mediating the negative regulation of $A \alpha$ gene expression. Several examples of both cis-acting DNA elements and trans-acting factors which can repress gene transcription have already been described (35). An example of a cis-acting DNA element that exerts a negative regulatory effect on gene transcription is the DNA element in the upstream region of the HMG coenzyme A reductase gene, in which positive and negative regulatory elements are closely associated (28). The large $\mathrm{T}$ antigen of simian virus $\mathbf{4 0}$ is a trans-acting repressor which regulates the synthesis of virus-coded proteins by decreasing the rate of early-strand RNA synthesis (40). In addition, proteins which displace or prevent the binding of positive trans-acting factors have recently been elucidated. For example, a CCAAT displacement protein which is present only in nuclear extracts from embryos in which the sperm $\mathrm{H} 2 \mathrm{~B}$ gene is inactive has been described. This protein binds to sequences overlapping the proximal CCAAT element of the sperm $\mathrm{H} 2 \mathrm{~B}$ promoter and thus prevents the binding of the CCAAT-binding factor (3). Glucocorticoids have long been known to inhibit the transcription of several genes, including collagen and stromelysin $(1,42)$. It has now been demonstrated that the same glucocorticoid receptor known to activate gene expression can lead to negative regulation by interfering with the binding or activity of positively acting factors (1).

We have currently identified two target sequences for B-cell nuclear proteins within fragment II of a HinfI digest of the 1.9-kb upstream regulatory region of the $A_{\alpha}{ }^{k}$ gene. The LPS-inducible DNA-binding protein binds preferentially to one of these regions, designated LRE. The previously described IL-4-inducible DNA-binding protein binds to a second sequence called BRE-2 (5). These target sequences are separated by only 20 bp (Fig. 6B). We have preliminary data (E. Gravallese and L. Glimcher, unpublished results) demonstrating that the LRE sequence is able to prevent binding of the IL-4-induced binding protein to fragment II, and conversely, that BRE-2 is able to prevent binding of the LPS-induced protein to fragment II. In addition, in two experiments the region of DNase I protection delineated by the LPS-induced nuclear extract showed modest protection of the BRE-2 target site. This may represent constitutive binding of the IL-4-induced protein, which is present at baseline in unstimulated nuclear extracts (5). Alternatively, it may demonstrate the ability of the LPS-induced DNAbinding protein to bind to either the LRE or the BRE-2 site. One possible model for $A \alpha$ gene regulation would be that two inducible DNA-binding proteins result from treatment with either LPS or IL-4 and that each protein is able to bind to either the LRE or the BRE-2 site. The LPS-inducible DNA-binding protein binds preferentially to the LRE sequence, as indicated by its characteristic pattern of DNase I protection and hypersensitivity. It is possible that protein binding to this sequence prevents the binding of positive regulatory elements such as the IL-4-inducible protein. The LPS-inducible DNA-binding protein could thus act as a negative regulator of $A \alpha$ gene expression. An alternative hypothesis is that a single protein is affected by both stimuli and binds preferentially to the LRE sequence only when affected by LPS. The target choice as well as the transcriptional effect would then depend upon the original external stimulus. Further studies are in progress to explore these possibilities.

\section{ACKNOWLEDGMENTS}

We thank Linda Blood for her expert assistance in the preparation of the manuscript and Michael Grusby for his critical review. We also thank Ranjan Sen and Hsou-Chi Liou for providing DNA fragments and oligonucleotides and Chris Lu for performing the Limulus lysate assays.

These studies were supported by Public Health Service grant GM36864 from the National Institutes of Health, by the March of Dimes Foundation, and by a Leukemia Scholar Award (L.H.G.).

\section{LITERATURE CITED}

1. Akerblom, I. E., E. P. Slater, M. Beato, J. D. Baxter, and P. L. Mellon. 1988. Negative regulation by glucocorticoids through interference with a cAMP responsive enhancer. Science 241: 350-353.

2. Baldwin, A. S., and P. A. Sharp. 1988. Two transcription factors, NF-kB and H2TF1, interact with a single regulatory sequence in the class I major histocompatibility complex promoter. Proc. Natl. Acad. Sci. USA 85:723-727.

3. Barberis, A., G. Superti-Furga, and M. Busslinger. 1987. Mutually exclusive interaction of the CCAAT-binding factor and of a displacement protein with overlapping sequences of a histone gene promoter. Cell 50:347-359.

4. Bauerle, P. A., and D. Baltimore. 1988. Activation of DNAbinding activity in an apparently cytoplasmic precursor of the NF-kB transcription factor. Cell 53:211-217.

5. Boothby, M., E. Gravallese, H.-C. Liou, and L. H. Glimcher. 1988. A DNA-binding protein regulated by IL-4 and by differentiation in B cells. Science 242:1559-1562.

6. Boothby, M., H.-C. Liou, and L. H. Glimcher. 1989. Differences in DNA sequence specificity among MHC class II X box binding proteins. J. Immunol. 142:1005-1014.

7. Breathnach, R., and P. Chambon. 1981. Organization and expression of eucaryotic split genes coding for proteins. Annu. Rev. Biochem. 50:349-383.

8. Chirgwin, J. M., A. E. Przybyla, R. J. MacDonald, and W. J. Rutter. 1979. Isolation of biologically active ribonucleic acid from sources enriched in ribonuclease. Biochemistry 18:5294 5299.

9. Dennis, G. J., J. Mizuguchi, V. McMillan, F. D. Finkelman, J. Ohara, and J. J. Mond. 1987. Comparison of the calcium requirement for the induction and maintenance of $\mathrm{B}$ cell class II molecule expression and for B cell proliferation stimulated by mitogens and purified growth factors. J. Immunol. 138:43074312 .

10. Dignam, J. D., R. M. Lebovitz, and R. G. Roeder. 1983. Accurate transcription initiation by RNA polymerase II in a soluble extract from isolated mammalian nuclei. Nucleic Acids Res. 11:1475-1490.

11. Dorn, A., B. Durand, C. Marfing, M. Le Meur, C. Benoist, and D. Mathis. 1987. Conserved major histocompatibility complex class II boxes - $\mathrm{X}$ and $\mathrm{Y}$ - are transcriptional control elements and specifically bind nuclear proteins. Proc. Natl. Acad. Sci. USA 84:6249-6253.

12. Dorn, A., H. J. Fehling, W. Koch, M. LeMeur, P. Gerlinger, C. Benoist, and D. Mathis. 1988. B-cell control region at the 5' end of a major histocompatibility complex class II gene: sequences and factors. Mol. Cell. Biol. 8:3975-3987.

13. Galas, D. J., and A. Schmitz. 1978. DNAase footprinting: a simple method for the detection of protein-DNA binding specificity. Nucleic Acids Res. 5:3157-3170. 
14. Germain, R. N., A. Bhattacharya, M. E. Dorf, and T. A. Springer. 1982. A single monoclonal anti-Ia antibody inhibits antigen-specific $\mathrm{T}$ cell proliferation controlled by distinct Ir genes mapping in different $\mathrm{H}-2$ I subregions. J. Immunol. 128:1409-1413.

15. Germain, R. N., and B. Malissen. 1986. Analysis of the expression and function of class-II major histocompatibility complexencoded molecules by DNA-mediated gene transfer. Annu. Rev. Immunol. 4:281-315.

16. Glass, C. K., J. M. Holloway, O. V. Devary, and M. G. Rosenfeld. 1988. The thyroid hormone receptor binds with opposite transcriptional effects to a common sequence motif in thyroid hormone and estrogen response elements. Cell 54: 313-323.

17. Goroff, D. K., A. Stall, J. J. Mond, and F. D. Finkelman. 1986. In vitro and in vivo B lymphocyte-activating properties of monoclonal anti-delta antibodies. J. Immunol. 136:2382-2392.

18. Halper, J., S. M. Fu, C. Y. Wang, R. Winchester, and H. G. Kunkel. 1978. Patterns of expression of human "Ia-like" antigens during the terminal stages of B-cell development. J. Immunol. 120:1480-1484.

19. Kuwabara, M. D., and D. S. Sigman. 1987. Footprinting DNAprotein complexes in situ following gel retardation assays using 1,10-phenanthroline-copper ion: Escherichia coli RNA polymerase-lac promoter complexes. Biochemistry 26:7234-7238.

20. Matis, L. A., L. H. Glimcher, W. E. Paul, and R. H. Schwartz. 1983. Magnitude of response of histocompatibility-restricted $\mathrm{T}$-cell clones is a function of the product of the concentrations of antigen and Ia molecules. Proc. Natl. Acad. Sci. USA 80: 6019-6023.

21. McMillan, V. M., G. J. Dennis, L. H. Glimcher, F. D. Finkelman, and J. J. Mond. 1988. Corticosteroid induction of $\mathrm{Ig}^{+} \mathrm{Ia}^{-}$B cells in vitro is mediated via interaction with the glucocorticoid cytoplasmic receptor. J. Immunol. 140:2549-2555.

22. Mond, J. J., E. Seghal, J. Kung, and F. D. Finkelman. 1981. Increased expression of I-region-associated antigen (Ia) on B cells after crosslinking of surface immunoglobulin. J. Immunol. 127:881-888.

23. Monroe, J. G., and J. C. Cambier. 1983. Level of mla expression on mitogen-stimulated murine B lymphocytes is dependent on position in cell cycle. J. Immunol. 130:626-631.

24. Morrison, D. C., and J. L. Ryan. 1979. Bacterial endotoxins and host immune responses. Adv. Immunol. 28:293-450.

25. Nguyen, H. T., R. M. Medford, and B. Nadal-Ginard. 1983. Reversibility of muscle differentiation in the absence of commitment: analysis of a myogenic cell line temperature-sensitive for commitment. Cell 34:281-293.

26. Noelle, R., P. H. Krammer, J. Ohara, J. W. Uhr, and E. S. Vitetta. 1984. Increased expression of Ia antigens on resting B cells: an additional role for B-cell growth factor. Proc. Natl. Acad. Sci. USA 81:6149-6153.

27. Noelle, R. J., W. A. Kuziel, C. R. Maliszewski, E. McAdams, E. S. Vitetta, and P. W. Tucker. 1986. Regulation of the expression of multiple class II genes in murine B cells by B cell stimulatory factor-1 (BSF-1). J. Immunol. 137:1718-1723.

28. Osborne, T. F., J. L. Goldstein, and M. S. Brown. 1985. 5' end of $\mathrm{HMG} \mathrm{CoA}$ reductase gene contains sequences responsible for cholesterol-mediated inhibition of transcription. Cell 42: 203-212.

29. Picard, D., and W. Schaffiner. 1984. A lymphocyte-specific enhancer in the mouse immunoglobulin $\kappa$ gene. Nature (London) 307:80-82.

30. Polla, B. S., J. Ohara, W. E. Paul, N. Nabavi, A. Myer, H.-C. Liou, F.-W. Shen, S. Gillis, J. V. Bonventre, and L. H. Glimcher. 1988. Differential induction of class II gene expression in murine pre-B-cell lines by B-cell stimulatory factor-1 and by antibodies to B-cell surface antigens. J. Mol. Cell. Immunol. 3:363-373.

31. Polla, B. S., A. Poljak, S. G. Geier, S. G. Nathenson, J. Ohara, W. E. Paul, and L. H. Glimcher. 1986. Three distinct signals can induce class II gene expression in a murine pre-B-cell line. Proc. Natl. Acad. Sci. USA 83:4878-4882.

32. Polla, B. S., A. Poljak, J. Ohara, W. E. Paul, and L. H. Glimcher. 1986. Regulation of class II gene expression: analysis in B cell stimulatory factor 1-inducible murine pre-B cell lines. J. Immunol. 137:3332-3337.

33. Rahmsdorf, H. J., N. Harth, A.-M. Eades, M. Litfin, M. Steinmetz, L. Forni, and P. Herrlich. 1986. Interferon- $\gamma$, mitomicin $\mathrm{C}$, and cycloheximide as regulatory agents of $\mathrm{MHC}$ class II-associated invariant chain expression. J. Immunol. 136:22932299.

34. Rigby, P. W. J., M. Dieckmann, C. Rhodes, and P. Berg. 1977. Labeling deoxyribonucleic acid to high specific activity in vitro by nick translation with DNA polymerase I. J. Mol. Biol. 113:237-251.

35. Sassone-Corsi, P., and E. Borrelli. 1986. Transcriptional regulation by trans-acting factors. Trends Genet. 2:315-319.

36. Schwartz, R. H. 1985. T-lymphocyte recognition of antigen in association with gene products of the major histocompatibility complex. Annu. Rev. Immunol. 3:237-261.

37. Sen, R., and D. Baltimore. 1986. Multiple nuclear factors interact with the immunoglobulin enhancer sequences. Cell 46:705-716.

38. Sen, R., and D. Baltimore. 1986. Inducibility of $\kappa$ immunoglobulin enhancer-binding protein $N F-\kappa B$ by a posttranslational mechanism. Cell 47:921-928.

39. Singh, H., J. H. LeBowitz, A. S. Baldwin, and P. A. Sharp. 1988. Molecular cloning of an enhancer binding protein: isolation by screening of an expression library with a recognition site DNA. Cell 52:415-423.

40. Tjian, R. 1978. The binding site on SV40 DNA for a $T$ antigen-related protein. Cell 13:165-172.

41. Turkewitz, A. P., C. P. Sullivan, and M. F. Mescher. 1983 Large-scale purification of murine $I-A^{k}$ and $I-E^{k}$ antigens and characterization of the purified proteins. Mol. Immun. 20: 1139-1147.

42. Weiner, F. R., M. J. Czaja, D. M. Jefferson, M.-A. Giambrone, R. Tur-Kaspa, L. M. Reid, and M. A. Zern. 1987. The effects of dexamethasone on in vitro collagen gene expression. J. Biol. Chem. 262:6955-6958. 